\title{
Indian strategic thinking about East Asia
}

\begin{abstract}
Since the end of the Cold War, India's strategic horizons have moved beyond its traditional preoccupations in South Asia. India is developing a strategic role in East Asia in particular. At the same time India's strategic thinking has undergone a revolution, as the country that prided itself on non-alignment has moved closer to the West. But India's culture, history and geography still fundamentally shape its worldview. In engaging with East Asia, India is guided by a mosaic of strategic objectives about extending its sphere of influence, developing a multipolar regional system and balancing against China. The interplay of these objectives will frame India's role in East Asia in coming years.
\end{abstract}

\section{Keywords}

India, strategic thought, East Asia, strategic autonomy, balance of power, sphere of influence

This article examines some of the key themes in strategic thinking that underlie and inform India's strategic engagement in East Asia.

Many believe that in the coming years India will assume an important role in the security of East Asia. There has been much discussion about India's Look East Policy and its growing engagement with East Asia, but there has been little consideration of Indian strategic thinking about the region. While India's engagement with East Asia is motivated in part by rivalry with China, Indian strategic thinking also remains very much a function of India's culture, history and geographic position.

This article will first provide an overview of India's strategic engagement with East Asia in recent years. Second, it will examine India's legacy of Nehruvian strategic doctrine and recent developments in strategic thinking. Third, it will examine India's long term quest for 
strategic autonomy and a multipolar regional order. Fourth, it will review Indian thinking about an Asian balance of power. Fifth it will reflect on ideological considerations in India's international relations. It will then consider India's maritime ambitions and ideas about an expanded sphere of influence for India that reaches into East Asia.

\section{India's engagement with East Asia}

This section will provide an overview of India's engagement with East Asia over the last two decades. ${ }^{1}$

The end of the Cold War was a major political, economic and strategic turning point for India. With the collapse of the Soviet Union India lost its strategic guarantor against China and its role as a leader of the non-aligned world. Almost simultaneously, India was plunged into its worst economic and political crises since Independence. These developments led to a fundamental reassessment of India's international relations. In 1992, India announced its "Look East Policy," which was initially focussed on expanding trade and investment ties with East Asia. India quickly developed good multilateral political links with the region, becoming an ASEAN dialogue partner in 1995, joining the ASEAN Regional Forum in 1996 and holding annual bilateral summits with ASEAN from 2002. With the support of the majority of ASEAN states, India joined the first East Asian Summit in 2005 and is now widely regarded as a likely member of any future Asian economic community.

Since the turn of the century, India has given greater emphasis to broader strategic objectives in the region. As Prime Minister Singh commented in 2005, the Look East policy is not merely an external economic policy, "but a strategic shift in India's vision." ${ }^{2}$ India has successfully developed a close partnership with Singapore as its economic, political and

\footnotetext{
${ }^{1}$ For discussions on India's strategic engagement with East Asia, see N.S.Sisodia and Sreeradha Datta, Changing Security Dynamics in Southeast Asia (New Delhi: Magnum Books, 2008); and David Brewster, India as an Asia Pacific Power (London: Routledge, 2011).

${ }^{2}$ Manmohan Singh, "Address at the 16th Asian Corporate Conference," Mumbai, 18 March 2006.
} 
security gateway to Southeast Asia. ${ }^{3}$ It has (with somewhat less success) attempted to transform its long term political alliance with Vietnam into a more broad-based security and economic relationship ${ }^{4}$ and is also developing closer relations with Indonesia, particularly in the sphere of maritime security cooperation. India has also made considerable progress in developing a strategic relationship with Japan, including ongoing broad-based security consultation and joint naval exercises, which was crowned by a joint Security Declaration in October $2008 .^{5}$

India's engagement with East Asia has occurred in the context of long term strategic competition with China. This is fed by their unresolved territorial dispute in the Himalayas, China's relationships with India's South Asian neighbours and India's fears of growing Chinese influence in Southeast Asia and the Indian Ocean region. While both India and China have generally been careful to keep such rivalry within bounds, many consider that strategic competition between them is likely to grow as India reaches for major power status. ${ }^{6}$ India's engagement with East Asia has been complemented by its developing security relationship with the United States. After years of steady improvements in political, economic and security relations, in July 2007 the two concluded negotiations on a nuclear cooperation agreement, which signaled a significant expansion of military and security relationships between them in the coming years. ${ }^{7}$

${ }^{3}$ See Asad-Ul Iqbal Latif, Between Rising Powers: China, Singapore and India, (Singapore: ISEAS Publishing, 2006).

${ }^{4}$ David Brewster, "The strategic relationship between India and Vietnam: The search for a diamond on the South China Sea?" Asian Security, 5/1 (January 2009), 24 - 44.

${ }^{5}$ See David Brewster, "The India - Japan Security Declaration: an enduring security partnership?" Asian Security, 6/2 (2010), 1-27.

${ }^{6}$ See generally, Francine R.Frankel and Harry Harding (eds.), The India-China Relationship: Rivalry and Engagement (New Delhi: Oxford University Press, 2004).

${ }^{7}$ For a discussion of the various dimensions of US-Indian strategic cooperation, see Sumit Ganguly, Brian Shoup, and Andrew Scobell (eds), US-Indian strategic cooperation into the 21st century: more than words (London: Routledge, 2006). 
Although India has had a significant degree of success in developing strategic relationships in East Asia, there remain important questions about India's objectives, particularly in the security dimension. Is India primarily driven by strategic rivalry with China? To what extent will India be drawn into the US alliance system in East Asia? Does India aim to become a major power in East Asia?

\section{The post-Cold War revolution in Indian strategic thinking}

India's engagement with East Asia has been accompanied by a revolution in Indian strategic thinking. Through much of the Cold War, Nehruvian strategic doctrine formed the intellectual foundation of Indian strategic analysis. At its core was the concept of nonalignment, which brought together several long-running strands of Indian strategic thought. As Nehru claimed, "I have not originated non-alignment: it is a policy inherent in the circumstances of India." ${ }^{8}$ The key principles of nonalignment were nonviolence, international cooperation and the preservation of India's international freedom of action through refusing to align India with any Cold War bloc. ${ }^{9}$ V.K. Krishna Menon characterised it as "the policy of independence" in which India took its decisions in her own national interests, in contrast with aligned states where decisions were placed "in foreign hands." 10 Nonalignment was given international effect through the Non-Alignment Movement which provided India with the status of a de facto leader of the third world. ${ }^{11}$ Although Indian strategic practice was progressively modified towards a more realist stance following India's defeat at the hands of China in 1962 and its strategic alignment with the Soviet Union in

\footnotetext{
${ }^{8}$ Rikhi Jaipal, Non-Alignment: Origins, Growth and Potential for World Peace (New Delhi: Allied Publishers, 1983), 8.

${ }^{9}$ Among the plethora of studies on nonalignment and Nehruvian strategic doctrine, see Mannaraswamighala Sreeranga Rajan, Studies on nonalignment and the nonaligned movement: theory and practice (New Delhi: ABC Publishing House, 1986); and K. Subrahmanyam, Indian security perspectives (New Delhi: ABC, 1982).

${ }^{10}$ Quoted in Sita Gopalan, India and Non-Alignment (New Delhi: Spick \& Span, 1984), 2.

${ }^{11}$ For a study of the Non Aligned Movement, see Jaipal, Non-Alignment.
} 
1971, Nehruvian strategic principles remained an intellectual anchor to Indian strategic thinking and dominated Indian strategic rhetoric up until the end of the Cold War. ${ }^{12}$

Nehruvian strategic doctrine inhibited India from playing a significant role in the security of East Asia until recently. Throughout much of the Cold War India saw its interests in East Asia as largely limited to rhetorical efforts to minimise the influence of other major powers. India abdicated any leadership role that it could have had in Southeast Asia and only really sought to exert its influence in negative terms, such as its emphatic rejection of regional security relationships with the United States. ${ }^{13}$ Nehruvian strategic doctrine also contributed to a virtual absence of any strategic relationships between India and maritime Northeast Asia. Throughout most of the Cold War, Indian leaders viewed Japan, South Korea and Taiwan as little more than protectorates of the United States and therefore of little interest to India except, in the case of Japan, as a potential source of capital and technology.

The end of the Cold War forced India to re-examine the viability of the Nehruvian principles in guiding India's strategic stance. With the collapse of the Soviet Union the idea of nonalignment seemed to have lost its raison d'être. India's leaders were forced to fashion a new set of strategic goals based on a more pragmatic view of the world. India's strategic options included attempting to continue with the logic of nonalignment, joining the US alliance system or attempting to balance against the United States through joining with other second-tier powers. Alternatively, it could pursue a multipolar world in which it would establish itself as one of the major powers in the international system without recourse to any alliance. While the notion of a triangular security relationship among India,

\footnotetext{
${ }^{12}$ The extent to which in practice (if not in rhetoric) India progressively abandoned non-alignment in favour of realist policies after 1962 is still a matter of much debate. See, for example, Rudra Chaudhuri, "Why Culture Matters: Revisiting the Sino-Indian Border War of 1962," Journal of Strategic Studies, 32/6 (December 2009), 841-869.

${ }^{13}$ For discussions of India's political relations in Southeast Asia during the Cold War see Mohammed Ayoob, India and Southeast Asia : Indian perceptions and policies (New York: Routledge, 1990) and Kripa Sridharan, The ASEAN Region in India's Foreign Policy (Aldershot: Dartmouth Publishing, 1996).
} 
Russia and China was debated within the Indian strategic community during the 1990s, there was a realisation that there was little to gain from seeking to create a countervailing bloc against the United States. By the end of the 1990s, the dominant emphasis in Indian strategic thinking had settled on building a new partnership with the United States as part of a multidirectional engagement of the major powers.

Many believe that India's Pokhran II nuclear tests in 1998 became the fulcrum around which India's post Cold War strategic thinking turned. Before the tests, India's ambiguous nuclear status created significant obstacles to improving relations with the United States and its allies. Although the nuclear tests caused a storm of protest internationally, it led to a transformation of India's relationship with the United States and also provided India with a new status in Asia. According to Mohan, after Pokhran II India's self-perception as an emerging great power armed with nuclear weapons allowed it to negotiate with other powers without the sense of defensiveness that had permeated earlier relationships. India's successful transition to a nuclear power also moved India's intellectual balance in favour of realists and pragmatists and effectively ended the long-standing dominance of Nehruvians and left-of-centre internationalists over the foreign policy discourse. ${ }^{14}$ Nevertheless, many of the underlying themes of nonalignment (e.g. strategic autonomy) still strongly influence Indian thinking.

There have been several attempts to characterise and define the various ideological schools in Indian strategic thinking as they have developed since the end of the Cold War. Bajpai identifies three paradigms of Indian strategic thinking: Nehruvianism, neoliberalism and hyper-realism, each characterised by differing attitudes towards internal security, regional security and relations with great powers and each of which are broadly associated with differing political ideologies. ${ }^{15}$ Sagar proposes a categorisation between moralists (who uphold the Nehruvian tradition), Hindu nationalists (who advocate protecting national

\footnotetext{
${ }^{14}$ C.Raja Mohan, Crossing the Rubicon: The Shaping of India's New Foreign Policy (New York: Palgrave Macmillan, 2003), 27.

${ }^{15}$ Kanti Bajpai, "Indian Strategic Culture" in Michael R. Chambers, South Asia in 2020: Future Strategic Balances and Alliances (Carlisle, PA: Strategic Studies Institute, 2002).
} 
values through building strength), strategists (secularists who advocate developing strategic capabilities) and liberals (who emphasise attaining security through trade and interdependence). ${ }^{16}$

These categorisations provide a useful context for understanding the main ideological streams of Indian strategic thinking. However, in considering India's strategic perceptions of East Asia such categorisations can quickly become sterile. Rather than attempting to identify a dominant or cohesive intellectual school of thought behind Indian strategic ambitions, it is in many ways more instructive to examine those ambitions in light of various underlying themes in Indian strategic thinking relevant to East Asia. One might see Indian strategic thinking in terms of a "mosaic" of many different threads and contrasting themes and influences which often cross ideological boundaries. This is partly a function of the immediate post-Cold War years, when Indian leadership allowed strategic policy to develop in a pragmatic way, generally avoiding a clear rejection of the past. Having flirted disastrously with grand concepts in the past, India's emphasis is on cautious realpolitik. ${ }^{17}$ Tellis suggests that India does not have the luxury of pursuing policies that are "utterly transparent or completely straightforward" and instead must develop the institutional and psychological capacity to move deftly. ${ }^{18}$ However, ambiguity or a lack of transparency over India's security objectives in East Asia has not prevented it from making significant steps towards engagement in the region.

Key themes in Indian strategic thinking relevant to its engagement with East Asia include its objectives of strategic autonomy and a multipolar order; concepts of an Asian balance of power; the ideological dimension; the development of a maritime strategic outlook; and ideas about an Indian sphere of influence. Each of these will be discussed in detail below.

\footnotetext{
${ }^{16}$ Rahul Sagar, "State of mind: what kind of power will India become," International Affairs, 85/4 (2009), 801-816.

${ }^{17}$ C.Raja Mohan, "India's Changing Strategic Profile in East and Southeast Asia," paper presented at the Regional Outlook Forum, Singapore, 8 January 2008, 12.

${ }^{18}$ Ashley J. Tellis, "India in Asian Geopolitics" in Prakash Nanda (ed.), Rising India: Friends and Foes, (New Delhi: Lancer, 2007) 129.
} 


\section{India's quest for strategic autonomy and a multipolar order}

Throughout its modern history India has sought what has been called the "Holy Grail" of Indian security policy: strategic autonomy. ${ }^{19}$ Since independence and before many Indian leaders saw India's destiny as a great power, beholden to no-one, even if it lacked the resources to assert itself in traditional ways. The combination of a destined greatness and material weakness was a key reason for India pursuing its nonaligned policy, allowing India to claim strategic space and assert itself as an international leader. India's destiny as a great power is now largely a given among Indian strategic thinkers and is virtually ubiquitous in strategic discussions; the only question being when the world will recognise India's emergence.

For many Indian strategists, strategic autonomy is the sine qua non of great power status. For some, particularly those strongly influenced by Nehruvian traditions, it is an absolute imperative: any compromise of India's strategic autonomy will also compromise India's destiny. This not only forbids significant security cooperation with the United States and its regional allies but would also cast doubt on any security alignments outside the US alliance system. An opposition to alliances was, of course, one of the core principles of nonalignment (although this principle did not prevent India from entering into a strategic alignment or partnership with the Soviet Union in 1971 to address the perceived threats posed by China and Pakistan). Others see the goal of strategic autonomy in less absolute or immediate terms, conceding that India's interests may be served in entering into security relationships with the United States and others provided that India retains significant freedom of action. Mohan for example argues that, "Alliance formation and balancing are tools in the kits of all great powers." 20 Closely related to India's "destiny" as a great power and its quest for strategic autonomy is a desire for the development of a multipolar security order in the region and worldwide which, it is believed, is necessary to elevate India's status

\footnotetext{
${ }^{19}$ Varun Sahni, “India and the Asian Security Architecture," Current History, 105 (690) (April 2006),
} 163-7.

${ }^{20}$ C.Raja Mohan, "India and the Balance of Power," Foreign Affairs, 85/ 4 (July/August 2006), 17. 
and maximise its freedom of action. To some extent calls for a multipolar world have replaced nonalignment as a core concept of Indian foreign policy.

India's twin goals of strategic autonomy and multipolarity have a profound impact on India's strategic engagement with East Asia. In order to achieve a goal of regional multipolarity, India not only must cooperate with other major powers (particularly the United States and Japan) to balance against potential Chinese hegemony in East Asia, but arguably is also indirectly driven to establish a sphere of influence in the Indian Ocean region. In pursuing those aims there are significant unresolved tensions between a desire for strategic autonomy and a perceived need to cooperate with the United States and its allies.

\section{Indian ideas on an Asian balance of power}

To what extent is the development of India's strategic relationships in East Asia driven by a strategy of forming a balancing coalition against China? India's potential role in an East Asian balance of power is an important theme in Indian strategic thinking. This might be expressed either in neorealist terms of creating a balancing coalition against China or in more classical realist terms of seeking to create a multipolar regional balance. Mohan claims that balancing China is in "the very DNA of India's geopolitics" and has been since the early 1950 s. $^{21}$

However, Indian thinking about an Asian balance of power is complicated by several factors. As discussed, Indian strategic thinking is still in the process of evolving from Nehruvian traditions in which discussions of a "balance of power" were frowned upon. Ideas of nonalignment still have resonance in Indian strategic debate, often with strong overtones of Indian exceptionalism. Sahni, for example, sees India as playing a new nonaligned role in the developing Asian strategic order. He believes that India is destined to be a fence-sitter in Asia, relatively equidistant and nonaligned between two poles of China and a US-led

\footnotetext{
${ }^{21}$ C.Raja Mohan, "The Evolution of Sino-Indian Relations: Implications for the United States," in Alyssa Ayres and C.Raja Mohan, Power Realignments in Asia: China, India and the United States, (New Delhi: Sage Publications, 2009), 270-290, at 288.
} 
coalition, although making significant efforts to cultivate friendships with powers such as Russia and Japan. ${ }^{22}$ In other words, India will again be able to transcend considerations of the balance of power, as Nehruvians claimed to have done during the Cold War.

Mohan, an Indian "modernist," believes that while it has not entirely discarded a commitment to liberal internationalist notions over the last two decades, Indian political discourse has had to come to terms with realist concepts of the balance of power. ${ }^{23}$ Certainly there is much more open discussion about an Asian balance of power than was the case during the Cold War. ${ }^{24}$ Although there is some official acknowledgement of what Defence Minister Mukherjee called India's "crucial" role in maintaining a "stable balance of power" 25 or an "equitable strategic balance" 26 in Southeast Asia, at the same time there is considerable reluctance to acknowledge that any balancing might be aimed at China. New Delhi is acutely conscious of its limitations in East Asia and is sensitive to any implication that its relationships in East Asia are driven by a desire to balance against China. ${ }^{27}$ India wishes to expand its strategic presence in the region while avoiding overt rivalry with China.

There is also considerable sensitivity as to how an overt balancing strategy would affect India's "Holy Grail" of strategic autonomy. In particular, to what extent would India need to ally itself with the United States and its regional allies in order to create an East Asian balance against China? Many see a significant risk that the United States will build India as a

\footnotetext{
${ }^{22}$ Rajesh Rajagopalan and Varun Sahni, "India and the Great Powers: Strategic Imperatives, Normative Necessities," South Asian Survey, 15/5 (2008), 5-32.

${ }^{23}$ C.Raja Mohan, "The Asian balance of power" Seminar, 487 (2000).

${ }^{24}$ See, for example, Anindya Batabyal, "Balancing China in Asia: A Realist Assessment of India's Look East Strategy," China Report (New Delhi), 42/2 (2006),79-197; and Bharat Karnad, "India's Future Plans and Defence Requirements" in N.Sisodia and C.Udaya Bhaskar (eds), Emerging India: Security and Foreign Policy Perspectives (New Delhi: Institute for Defence Studies and Analysis, 2005), 61-76. ${ }^{25}$ Pranab Mukherjee, Address to the 5th IISS Asian Security Summit, 3 June 2006.

${ }^{26}$ Pranab Mukherjee, Address to the 7th Asian Security Conference, 29 January 2005.

${ }^{27}$ Sudhir Devare, India and Southeast Asia: Towards Security Convergence, (Singapore: Institute of Southeast Asian Studies, 2006), 211.
} 
junior alliance partner to contain China and that India will be caught in a web of bilateral arrangements that meshes with the US "hub and spoke" alliance system. ${ }^{28}$ Thus there was considerable caution in parts of the Indian security community about the 2007 "Quadrilateral" proposal for a security dialogue involving the United States, Japan, Australia and India on the grounds of being perceived to be part of a US-led security grouping. According to Tellis, even if an anti-China coalition led by the United States were to eventuate in the future, New Delhi's intuitive preference would be to assert its strategic autonomy even more forcefully. Short of the most extreme threats, India would prefer to deal with Beijing independently. ${ }^{29}$

There is also a tendency among Indian strategic analysts of all stripes to see India as of significantly greater consequence to an East Asian balance of power than might be perceived in East Asia - where the focus is overwhelmingly on the United States, China and, to a lesser extent, Japan. An internal report by the CIA's National Intelligence Council which called India the most important "swing state" in the international system ${ }^{30}$ is quoted widely and approvingly among Indian leaders and commentators, recognising as it does an apparently powerful international role for India. ${ }^{31}$ In a similar vein, Mohan argues that

\footnotetext{
${ }^{28}$ Purnendra Jain, “From Condemnation to Strategic Partnership: Japan's Changing View of India (1998-2007)", Institute of South Asian Studies Working Paper No.41, 10 March 2008; and Brahma Chellaney and Horimoto Takenori, "“'Indo kara mita Nihon, Ajia“ [Japan-India Links Critical for AsiaPacific Security] Gaiko Forum, 7/2 (Fall 2007).

${ }^{29}$ Ashley J.Tellis, "The Changing Political-Military Environment: South Asia" in Zalmay Khalilzad et al, The United States and Asia: Towards a New US Strategy and Force Posture (Santa Monica: Rand Corporation, 2001) at 214.

${ }^{30}$ Non-public report, quoted in Ashley Tellis, India as a New Global Power: An Action Agenda for the United States (Washington D.C.: Carnegie Endowment for World Peace, 2005).

${ }^{31}$ See, for example, Siddharth Varadarajan, "Bush, India and two degrees of separation," The Hindu, 3 March 2006; Amit Gupta, "US-India-China: Assessing Tripolarity," China Report (New Delhi), 42/1, (2006), 69-83; Mohan, "India and the Balance of Power," p.17; and Rajiv Sikri, Challenge and Strategy: Rethinking India's Foreign Policy (New Delhi: Sage, 2009).
} 
India's objective is to become an indispensable element in the Asian balance of power. ${ }^{32}$ To the extent that such a statement suggests that India is likely to become an important element in an Asian balance of power, it is unexceptional. However, to the extent that it implies that India has the option not to oppose Chinese hegemony over East Asia, it overstates India's freedom of action. It is difficult to realistically conceive of India not seeking to balance against China in Asia in one way or another. Arguably, India is in fact compelled by its own great power aspirations to seek to form (limited) balancing relationships with the United States and its allies in relation to China.

Spurred by dreams of strategic autonomy and a multipolar region, some Indian "hawks" have gone so far as to propose that India should develop an Indian-centred "constellation" of Asian states linked by cooperation and common interests, including in counterbalancing China. Chellaney, for example, sees the India - Japan relationship as forming the potential foundation of overlapping security relationships in Asia. The relationship would provide India with a link into the US security sphere, forming the foundation of a coalition that includes the United States and Australia. However, India would also develop a series of balancing relationships that go beyond the US security sphere, including, for example, an India-Japan-Russian trilateral relationship which, according to Chellaney, is the way to get a "true counterbalance to China" because it "would effectively contain China on all sides." 33 India's security relationship with Vietnam is also widely viewed in the Indian security community in approving terms, partly at least because Vietnam lies outside the US security sphere.

Despite these dreams there is also a widespread understanding in the Indian security community that a strategic relationship with United States is a necessary or desirable feature of Indian security, if only as a step towards other strategic objectives. Some believe that India's challenge will be to form part of an informal balancing coalition against China with the US and its allies while avoiding becoming part of a US-led web of relationships. Bajpai, a leading neoliberal, characterises Indian policy since the end of the Cold War as

32 C.Raja Mohan, "India, China and Asian Security," The Hindu, January 27, 2003.

33 Chellaney, "Indo kara mita Nihon, Ajia." 
essentially bandwagoning with the United States, while also hedging in the sense of developing coalitions with first, second and third tier states that would assist it in standing up to the United States. ${ }^{34}$ Others see the possibility of India occupying a middle ground of partial attachment to the United States while retaining significant strategic autonomy. Mohan endorses the idea that India can navigate between the "two extremes" of an uncritical US alliance and what he calls the "slogans" of a multipolar world. A somewhat ambiguous approach would likely fit well with India's strategic tradition and domestic political imperatives. Ambiguity could also be used to India's advantage, for example, in allowing India to be cast within East Asia as a benign balancer not only against a potentially threatening China but also (if perhaps only symbolically) against potentially overwhelming US power.

\section{The ideological dimension: flirting with values-based alliances}

To what extent does India's strategic behaviour in East Asia involve an ideological dimension? A notable feature of Nehruvian strategic doctrine was that India rarely allowed domestic political affairs of other states to be a significant factor in India's foreign policy decision-making. As a result of its colonial experience, India placed national sovereignty above liberal values. To the extent that India's foreign policy had an ideological dimension it often involved an alliance with communist or authoritarian states in opposing the supposed imperialism of the West. However, in recent years Indian leaders have begun to make considerable use of the rhetoric of "shared democratic values" as justification for cooperation with Japan and other US allies in the region, to the exclusion of China. Prime Minister Manmohan Singh has called liberal democracy "the natural order of social and political organisation," 35 describing India and Japan, the largest and most developed

\footnotetext{
${ }^{34}$ Kanti Bajpai, "India: Modified Structuralism," in Muthiah Alagappa (ed.), Asian Security Practice: Material and Ideational Influences (Stanford: Stanford University Press, 1998).

${ }^{35}$ Manmohan Singh, "PM's Speech at India Today Conclave" 25 February 2005, New Delhi. $<w w w . p m i n d i a . n i c . i n / s p e e c h / c o n t e n t . a s p ? i d=510>$.
} 
democracies in Asia, as being "natural partners." ${ }^{36}$ Such statements are consistent with past efforts by the United States and Japan to use shared democratic values as an ideological foundation for strategic relationships with India. ${ }^{37}$

Some Indian commentators have suggested that shared political values represent a "secret weapon" against China on the basis that China has much more to fear from the ideological subversion of democracy than in military terms, ${ }^{38}$ while others have invoked the theory of "Democratic Peace" to justify India forming alliances with other regional democracies. ${ }^{39}$ The significance of alliances among democratic states is a matter of some theoretical debate. It has little support from the so-called theory of "Democratic Peace" which proposes that democratic states never (or rarely) go to war with each other, but not the idea that democracies will or should become alliance partners against non-democracies. Some theorists nevertheless suggest that members of ideological-based alliances may have similarities in threat perceptions, ${ }^{40}$ and that alliances between democracies are both deeper and longer lasting than alliances with non-democracies. ${ }^{41}$ It has also been argued that as a great power matures, it will increasingly seek to shape its region and the international order in ways that reflect its values and identity. ${ }^{42}$ According to this argument, as a great power,

\footnotetext{
${ }^{36}$ Joint Statement of Prime Minister Singh and Prime Minister Abe, 16 December 2006. <http://www.kantei.go.jp/foreign/abespeech/2006/12/15joint.pdf>.

${ }^{37}$ This represented a new approach for Japan, but clearly forms a key element in both neo-liberal and neo-conservative thinking in the United States. See generally, G.John Ikenberry, Liberal order and imperial ambition: essays on American power and world politics (Malden, MA : Polity, 2006).

${ }^{38}$ B.Raman, "India \& Japan: Democracy as a Strategic Weapon" South Asia Analysis Group, Paper No. 206, 17 December 2006.

${ }^{39}$ Brahma Chellaney, "Towards Asian power equilibrium," The Hindu, 1 November 2008.

${ }^{40}$ Stephen M. Walt, The Origins of Alliances (Ithaca: Cornell University Press, 1987), 266.

${ }^{41}$ Victor D. Cha, "The Ideational Dimension of America's Alliances in Asia," in Amitav Acharya and Evelyn Goh (eds.), Reassessing Security Cooperation in the Asia Pacific: Competition, Congruence and Transformation (Cambridge: The MIT Press, 2007), 41-70.

${ }^{42}$ Ikenberry, Liberal order and imperial ambition.
} 
India might eventually seek to impose its own values on Asia despite its avowed policy of not exporting ideology.

However, for the moment, ideology plays only a very minor part in India's strategic engagement in East Asia, either as a motivation or as a tool of "soft power." Democratic values form part of a rhetorical package of shared interests between India and the United States and others such as Japan, South Korea and Australia, something which India has also found useful in differentiating itself from its two principal strategic adversaries, Pakistan and China. ${ }^{43}$ However there is little history of democratic values playing a significant role in East Asian strategic relationships and democratic values (or the lack of them) seem to have been little impediment to the development of India's relationships with Singapore or Vietnam. India has also demonstrated a willingness to abandon democracy as a guiding principle where it believes that its interests are otherwise threatened (e.g. when support for Burma's democratic opposition was reversed in the face of China's increased influence with the Burmese junta). As Indian Foreign Secretary Shyam Saran commented, although “democracy remains India's biding conviction, the importance of our neighbourhood requires that we remain engaged with whichever government is exercising authority in any country." 44

\section{India as a maritime power}

A new and potentially important element in Indian strategic thinking is a partial reorientation in India's strategic outlook from purely continentalist towards a more maritimist perspective. This helps fuel India's ambition to become the predominant naval power in the Indian Ocean region, an ambition which has significant consequences on India's security role in Southeast Asia.

\footnotetext{
${ }^{43}$ C.Raja Mohan, "Balancing Interests and Values: India's Struggle with Democracy Promotion," The Washington Quarterly, 30/3 (Summer 2007), 99-115.

${ }^{44}$ Shyam Saran, "India and its Neighbours", address in New Delhi, 14 February 2005. $<$ www.meaindia.nic.in>.
} 
Indian security thinking has traditionally tended to take a "continental" outlook. For thousands of years military threats to India have been perceived as coming primarily from India's north-west. This was reinforced by India's experience in the twentieth century, when direct military threats to India were land-based: from the north-east (Japan, 1941-45), the north-west (Pakistan, 1947 and after) and the north (China, 1962 and after). The continuing threats on India's western and northern borders and from domestic insurgencies has led to the Indian Army holding an undisputedly dominant position within the Indian military establishment, in comparison to which the Indian Navy and its supporters have had little strategic influence.

Despite this tradition there is a developing view among some Indian strategists of India as primarily a maritime and not a continental power. According to some New Delhi is making a conscious effort to expand the Indian "mental map" in strategic affairs to include the seafaring dimension which can be compared with the fundamental shifts in strategic culture experienced by Japan and the United States in the nineteenth century. ${ }^{45}$ Many Indian naval leaders and commentators argue that India's peninsular character and central position in the Indian Ocean gives the sea a preponderant influence over its destiny. The former Indian Chief of Naval Staff, Admiral Sushil Kumar claimed that under the previous BJP government, "India's national interest had been made coterminous with maritime security." 46 Other Indian leaders have drawn a close connection between India's maritime ambitions and its destiny as a great power. As Indian Foreign Minister Pranab Mukherjee commented in June 2007, "Fortunately, after nearly a millennia of inward and landward focus, we are once again turning our gaze outwards and seawards, which is the natural direction of view for a nation seeking to re-establish itself, not simply as a continental power, but even more so as a maritime power, and consequently as one that is of significance on the world stage

\footnotetext{
${ }^{45}$ James R. Holmes, Andrew C. Winner and Toshi Yoshihara, Indian Naval Strategy in the 21st Century (London, Routledge, 2009), 33.

${ }^{46}$ Quoted in David Scott, "India's "Grand Strategy for the Indian Ocean: Mahanian Visions," AsiaPacific Review, 13/2 (2006),97-129 at 109.
} 
(emphasis added)." 47 Such thinking seems to echo the views of other great power aspirants such as the former Soviet Union and China that maritime power is a sine qua non of great power status. Geography also suggests that any significant expansion of Indian influence can only take place in the maritime domain. The Himalayas provide a formidable barrier to India's ability to project power and influence northwards into continental Asia. As Rajiv Sikri, a former Secretary in India's Foreign Ministry commented: "If India aspires to be a great power, then the only direction in which India's strategic influence can spread is across the seas. In every other direction there are formidable constraints." 48

Many commentators have observed that geopolitical theories, particularly focusing on maritime power, have become prominent in strategic analysis in both India and China. ${ }^{49}$ Mohan believes it a natural consequence of a shift of both China and India from inward leaning to outward leaning economies, commenting that: "The sneering tone of the West vis a vis the Chinese and Indian fascination for geopolitics tells us more about the ethnocentrism in the West and its belief that the dominant view of the West today must necessarily be the prevailing fashion all across the world..." 50 According to geopolitical analysis, maritime and continental strategic outlooks differ in fundamental respects. A maritime strategic perspective focuses on the importance of securing sea lines of communication and key choke points joining bodies of water. Geopolitical theory also often distinguishes between the characters of states within the "continental" and "maritime" realms. The influential geopolitical theorist, Saul Cohen, divides the world into a "Maritime" realm (which includes Japan and other trade dependent East Asian states), a "Continental"

\footnotetext{
${ }^{47}$ Pranab Mukherjee, Speech for the Admiral A. K. Chatterjee Memorial Lecture, Kolkata, 30 June 2007.

${ }^{48}$ Sikri, Challenge and Strategy, 250.

${ }^{49}$ For example, Scott, "India's "Grand Strategy for the Indian Ocean: Mahanian Visions," at 109; and Banyan, "The notion that geography is power is making an unwelcome comeback in Asia" The Economist, 11 June 2009.

${ }^{50}$ C.Raja Mohan, "Maritime Power: India and China turn to Mahan," ISAS Working Paper No. 71,7 July 2009, 9.
} 
realm (which includes Russia and, historically, China) ${ }^{51}$ and a mixed maritime/continental realm. The difference is considered critical not only in terms of the manner of military power projection, but in general strategic outlook and underlying economic and political systems. Maritime states are often characterized as liberal both economically and politically, in contrast to continental states that tend to be economically illiberal and authoritarian. Thus maritime Britain is contrasted with (pre-war) continental Germany ${ }^{52}$ and the maritime United States with continental Russia. ${ }^{53}$

There is no clear consensus among geopolitical theorists as to where India fits in this picture, although some believe that India has the capacity to have either a continental or maritime focus. Karnad, a leading Indian nuclear theorist and "realist", argues that India has the flexibility to choose between a maritime or continental perspective and in doing so is able to tip the balance for or against the mainly maritimist United States in its contest with a continentalist China. ${ }^{54}$ Questions of maritime versus continental perspectives also underlie the debate as to whether the centre of gravity of India's strategic orientation should lie towards West and Central Asia, a region which could be characterized as predominantly continentalist in outlook (with the exception of the small Gulf states) or towards East Asia which is arguably more maritime in nature.

The most immediate impact of a reorientation in India's strategic outlook is its strengthened focus on attaining naval predominance in the Indian Ocean region. India's standing as the most populous state in the Indian Ocean region and its central position in the northern Indian Ocean have long contributed to beliefs in New Delhi about India's destiny to control its eponymous ocean. Even before India's independence, K.M. Panikkar, India's most famous maritime strategist, argued that the Indian Ocean must remain "truly Indian"

\footnotetext{
${ }^{51}$ Saul Bernard Cohen, Geopolitics of the World System (Lanham: Rowman \& Littlefield, 2003). ${ }^{52}$ See, for example, H. van der Wusten; G. Dijkink, "German, British and French Geopolitics: The Enduring Differences," Geopolitics, 7/ 3 (Winter 2002), 19- 38.

${ }^{53}$ Colin S. Gray, The geopolitics of the nuclear era: heartland, rimlands, and the technological revolution (New York: Crane, Russak, 1977).

${ }^{54}$ Karnad, "India's Future Plans and Defence Requirements," 62-63 (note 98).
} 
advocating the creation of a "steel ring" around India through the establishment of forward naval bases in Singapore, Mauritius, Yemen and Sri Lanka. ${ }^{55}$ According to some reports there is now a "well established tradition" among the Indian strategic community that the Indian Ocean is, or should be, "India's Ocean." 56

Many believe that the Indian Navy has come to see itself as destined to become the predominant maritime security provider in a region stretching from the Red Sea to Singapore and having a significant security role in areas beyond, including the South China Sea. Others also believe that control of the Indian Ocean (including the chokepoints into the Pacific Ocean) could enhance India's bargaining position with the whole of maritime Asia. Alfred Thayer Mahan, the nineteenth century American naval strategist, is quoted widely and approvingly among Indian strategic thinkers including a statement attributed to Mahan that: "Whoever controls the Indian Ocean dominates Asia....In the 21st century, the destiny of the world will be decided on its waters." Although the attribution of the statement has been shown to be fictitious, it has not inhibited the enthusiasm for the ideas that it carries. ${ }^{57}$

India's ambitions for predominance in the Indian Ocean region underpin India's security ambitions in maritime Southeast Asia. Over the last two decades, the Indian Navy has played an active role in extending India's influence throughout the Indian Ocean region and maritime Southeast Asia and Northeast Asia. ${ }^{58}$ India has placed significant emphasis on achieving a predominant position in the Bay of Bengal and the western approaches to the Malacca Strait with the development of naval facilities in the Andaman Islands during the 1990s. It has been suggested that for India, the Malacca Strait represents a rough

${ }^{55}$ K.M.Panikkar, India and the Indian Ocean: An Essay on the Influence of Sea Power in Indian History (Bombay: George Allen \& Unwin, 1971).

${ }^{56}$ Scott, "India's "Grand Strategy" for the Indian Ocean," at 99

${ }^{57}$ See generally, Rahul Roy-Chaudhury, Sea Power and India's Security (London: Brassey's, 1995), 199.

${ }^{58}$ David Scott, "India's Drive for a Blue Water Navy," Journal of Military and Strategic Studies, 10/2 (Winter 2007-08), 1-42. 
counterpart to the importance of the Panama Canal to the United States in terms of maintaining regional hegemony. ${ }^{59}$ The Malacca Strait (which is largely within Indonesian and Malaysian territorial waters) lies on the major sea line of communication and represents the main choke point between the Pacific and Indian Oceans. Indian control over the Strait and a security presence in Southeast Asia is seen by some as a prerequisite of effective control of the eastern Indian Ocean. None of this is new. In the 1940s, Panikkar recognized the particular importance of Singapore to India as the eastern anchor of India's maritime security, predicting that India would be a principal security provider to Singapore. ${ }^{60}$ For some years, the Indian Navy has sought a direct security role inside the Strait, a significant factor underlying India's strategic relationships with Indonesia, ${ }^{61}$ and wants to develop the capability to project naval power into the South China Sea, which is a significant factor in India's security relationship with Vietnam. ${ }^{62}$ Mohan claims that as the Indian economy grows and it modernises its military capabilities it will become an attractive strategic partner in East Asia, generating strategic "options that did not exist before in the Western Pacific." 63

There are, however, limits to India's re-orientation towards a maritime perspective. Some criticize the Indian Navy's ambitions, claiming that India will always be a continental state. Sahni, for example, warns that the Soviet Union's failed attempts to become a naval power in the 1970s and 1980s should act as "a cautionary tale for India's Mahanian navalists.... a grim warning of what happens to a continental state that harbours overly grandiose maritime ambitions." 64 Sahni suggests that India should move away from following a "sea

\footnotetext{
${ }^{59}$ Holmes et al, Indian Naval Strategy in the 21st Century, 154.

${ }^{60}$ K.M. Panikkar, The Future of Southeast Asia: An Indian View, (New York: The Macmillan Company, 1943), 100-1.

${ }^{61}$ David Brewster, "The evolving security relationship between India and Indonesia" Asian Survey, 51/2 (March/April 2011), 221-244.

${ }^{62}$ Brewster, "India's Strategic Partnership with Vietnam."

${ }^{63}$ C.Raja Mohan, "Is India an East Asian Power? Explaining New Delhi's Security Politics in the Western Pacific," ISAS Working Paper No.81, 11 August 2009.

${ }^{64}$ Varun Sahni, “India's Security Challenges out to 2000" paper presented at the Australia-India Security Roundtable, Canberra, 11-12 April 2005. Mahan also harboured significant doubts about
} 
control" strategy based around expensive and vulnerable aircraft carriers and follow a "sea denial" strategy based on submarines. Further, given India's renowned lack of coordination in strategic planning, the Indian Navy's activist role in the Indian Ocean region and Southeast Asia should not always be assumed as reflecting a unified position in the government or the armed services and there is long running tension between the Indian Navy and Ministry of External Affairs over the navy's assertive regional policy, including its role in anti-piracy operations off Somalia.

Despite these caveats, there are grounds to believe that a maritime perspective holds a significantly stronger place in Indian strategic thinking than in previous times.

\section{An Indian sphere of influence?}

Related to the increased prominence of maritime perspectives is a revival in thinking about an Indian sphere of influence in the Indian Ocean region, potentially extending into Southeast Asia. While such ideas can, in part, be viewed as a reaction to perceived incursions of China into India's neighbourhood, they should be seen as primarily springing from India's ambitions as a major regional power.

Discussions of an Indian sphere of influence beyond South Asia are sometimes identified with Lord Curzon, the British Viceroy of India at the beginning of the twentieth century, who advocated that British India adopt a "Forward Policy" to secure India. Curzon's so-called "Forward School" argued that India's security demanded control of the maritime routes and key ports en route to India (including Aden and Singapore) and the creation of territorial buffers to insulate direct contact with other empires (including Afghanistan in the west, Tibet in the north and Siam in the east) and for British India to take an active role in managing the affairs of the buffer zones.

the ability of the United States to transform itself into a maritime power. See A.T.Mahan, The Influence of Sea Power on History, 1660-1783 (Boston: Little Brown \& Co) 83-88. 
In many ways the policies of the British Raj represented a significant departure from Indian traditions, which had little history of territorial expansion or military or political adventure beyond the limits of the subcontinent. Many characterise Indian strategic behaviour as defensive or reactive. According, to K. Subrahmanyam, called the "doyen" of Indian strategists by the current Prime Minister, "The essential Indian weakness, which our adversaries are well aware of, is the total lack of a tradition of strategic thinking and our reactive style of decision making in every sphere." 65 Tanham's study of India's strategic culture in the early 1990s characterised Indian strategic thinking as being "defensive" and having a "lack of an expansionist military tradition." 66 Certainly, any affirmation of an Indian security sphere beyond South Asia largely ceased following independence. After 1947, India effectively withdrew to the Indian subcontinent and asserted what has been called "India's Monroe Doctrine" according to which India would not permit any intervention by any "external" power in South Asia and related islands. While India had only limited success in this policy, India's Monroe Doctrine was used to justify interventions in India's smaller neighbours such as Sri Lanka and Maldives. ${ }^{67}$ An exception to this limited area of influence was Indochina, where during the Cold War India developed a strong political relationship with Vietnam in an effort to limit the influence of China and other "external" powers in that subregion. Indian leaders and strategists claimed that Vietnam guarded the eastern flank of India's "core sphere of influence" in South Asia. ${ }^{68}$

Since the end of the Cold War there has been a revival in discussion in India about a "natural" sphere of influence extending well beyond the Indian subcontinent. This is

\footnotetext{
${ }^{65}$ K. Subrahmanyam, "Slumber over National Security" Economic Times (New Delhi), 31 October 2000.

${ }^{66}$ George Tanham, "Indian Strategic Thought: An Interpretive Essay," in George K. Tanham, Kanti P. Bajpai and Amitabh Mattoo (eds), Securing India: Strategic Thought and Practice in an Emerging Power, (New Delhi: Manhora, 1996), 73.

${ }^{67}$ James R.Holmes and Toshi Yoshihara, "India's 'Monroe Doctrine' and Asia's Maritime Future," Strategic Analysis, 32/6 (November 2008), 997- 1011.

${ }^{68}$ According to Indira Gandhi. See John W.Garver, "Chinese-Indian Rivalry in Indochina," Asian Survey, 27/11 (Nov. 1987), 1205-1219 at 1207-8.
} 
related to attempts to move beyond India's strategic preoccupations in South Asia and reengage with its extended neighbourhood so as to rectify what Foreign Minister Jaswant Singh called India's unnecessary acceptance of "the post-Partition limits geography imposed on policy." 69 In 2001, the Ministry of Defence Annual Report described what it called India's security environment as extending from the Persian Gulf in the west, to the Straits of Malacca in the east, ${ }^{70}$ an area which the former BJP Foreign Minister Jaswant Singh called India's sphere of influence ${ }^{71}$ and the current Prime Minister Manmohan Singh has perhaps more diplomatically called India's strategic footprint. ${ }^{72}$ Some have tried to re-articulate the geographical idea of "South Asia" (in which India is naturally predominant) towards a concept of "Southern Asia", a region extending from the Persian Gulf to Singapore (in which India will grow to dominate). Subrahmanyam proclaimed that it is India's "manifest destiny to control Southern Asia and the Indian Ocean sea-lanes around us." ${ }^{\prime 3}$ (emphasis added) His words were no doubt intended to evoke claims by the United States to a special role in the Western Hemisphere.

Mohan has labelled India's reach into its extended neighbourhood over the last decade or more as a neo-Curzonian "Forward Policy," claiming:

"The end of the cold war and the efforts to globalise the economy put India willy-nilly on the path of a new forward policy. India never consciously articulated its approach in terms of theory that demanded activism in the neighbouring regions to enhance its own security. Its regional initiatives were presented in terms of mutual economic benefit and the restoration of historic links, but their strategic significance was unmistakable."74

\footnotetext{
${ }^{69}$ Mohan, Crossing the Rubicon, 205.

${ }^{70}$ Ministry of Defence, Annual Report 2000-2001.

${ }^{71}$ Chidanand Rajghatta, "Singhing Bush's Praise,"Times of India, 13 April 2001.

72 "PM's Address at the Combined Commander's Conference," 24 October 2004.

${ }^{73}$ Quoted in Holmes et al, Indian Naval Strategy in the 21st Century, 38.

${ }^{74}$ Mohan, Crossing the Rubicon, 209.
} 
Suggestions that India is pursuing (or should pursue) a new Forward Policy have been strongly criticised by some Indian strategists seeing it as an inappropriate, irrelevant or "quixotic" attempt to return to imperial thinking. Despite such criticism, it is not difficult to view India's strategic engagement with East Asia, and particularly with Southeast Asia, as having elements of a reassertion of British India's sphere of influence centred on the Indian Ocean and extending from Aden to Singapore. In the east one might see Indian hopes to develop Burma as a buffer state against China, while India gains maritime predominance in the Bay of Bengal/Andaman Sea and a major role in the Malacca Strait. Singapore would act as the eastern "anchor" to this space. In the west India exerts influence in Afghanistan while it renews its historical relationships with the Gulf States and Iran. ${ }^{75}$

While there are indications of India's ambitions to build something that might be called a "sphere of influence" there is little guidance as to what it might look like, particularly in Southeast Asia. Certainly, India's approach to building a sphere of influence from Aden to Singapore differs significantly from Lord Curzon's. India has no choice but to accept that it must develop its influence in a non-confrontational way. As Foreign Minister Pranab Mukherjee commented (in relation to South Asia): "India does not seek an exclusive sphere of influence, but a shared sphere of mutual development and cooperation." 76 Similarly, Mohan argues that New Delhi is unlikely to make an attempt to regain the hegemonic role of British India in the Indian Ocean region. ${ }^{77}$ India's cooperative approach to developing security relationships has been evident in Southeast Asia, where the Indian navy has been successful in developing good relationships in the region and has displayed sensitivity towards local political concerns in relation to the Malacca Strait.

The failure of India to project military power beyond the limits of South Asia during the Cold War has placed India in good stead in East Asia. India has a noticeable lack of historical baggage in its dealings in the region, perhaps with the exception of the Islamic factor arising

\footnotetext{
${ }^{75}$ For a discussion of India's security relationships throughout the Indian Ocean, see David Brewster "An Indian sphere of influence in the Indian Ocean?" Security Challenges , 6/3 (Spring 2010), 1-20.

${ }^{76}$ Amit Baruah, "Not seeking exclusive sphere of influence," The Hindu, 11 February 2007.

${ }^{77}$ Mohan, Crossing the Rubicon, ch.8.
} 
from India's conflict with Pakistan. India is commonly perceived in Southeast Asia as essentially a benign power and not a would-be hegemon, often in contrast with other powers such as China, the United States and Japan. According to some, India's track record of nonaggression, its cultural and philosophical virtues, and its ethnic and religious ties to Southeast Asia lend credence to Indian soft power diplomacy. ${ }^{78}$ While India is not in a position to exert significant power through military predominance or ideological means, it may be able to do so as a provider of public goods. ${ }^{79}$ In the early 1990s, Tanham described India's regional ambitions in the following terms:

"Strategically, India aspires to be a friendly international peacekeeper. It sees itself as a benevolent nation and a friendly policeman that seeks peace and stability for the entire Indian Ocean region. It denies any hegemonistic designs or territorial ambitions. It vehemently rejects and resents charges of being a regional bully. It wants not only to play the role of regional peace-keeper but also to be acknowledged and endorsed in that role by others, especially the great powers." 80

India shows a strong desire to expand its presence in the region as a benign and cooperative maritime security provider. Over the last decade it has proffered its capabilities in disaster relief (such as during the 2004 Tsunami) and in maritime policing in the Andaman Sea (including in dealing with piracy, smuggling and arms trafficking). Since the mid-1990s, the Indian Navy has hosted the biennial MILAN naval "meeting" of regional navies in the Andaman Islands. In 2008 the Indian Navy sponsored the establishment of the Indian Ocean Naval Symposium, a biennial meeting of naval chiefs from all Indian Ocean states modelled on the US-sponsored Western Pacific Naval Symposium. These are often portrayed as successful examples of cooperative naval diplomacy by the Indian Navy and may help mitigate concerns about India's intentions. However, at the same time, India has been

\footnotetext{
${ }^{78}$ Holmes et al, Indian Naval Strategy in the 21st Century,155.

${ }^{79}$ For a discussion of these different ways of exerting hegemony, see Rajagopalan, "India and the Great Powers".

${ }^{80}$ Tanham, “Indian Strategic Thought," 69.
} 
careful to exclude both the United States and China from such gatherings, thereby emphasising India's leading role.

Nevertheless, as it expands its influence in the Indian Ocean and Southeast Asia, India has had to accept that other major powers will continue to have significant interests in the region. The United States, particularly with its base at Diego Garcia and its naval facilities in Singapore and the Gulf, seems likely to remain the predominant naval power in the Indian Ocean region for some time to come. However, there are indications that the United States is willing to cede - and indeed encourage - a major regional naval role for India across the Indian Ocean, including in or around the Malacca Strait. For its part, India's willingness to cooperate with the United States in achieving its ambitions is not as paradoxical as it may seem. As the former US Secretary of State, Dean Acheson, once conceded, the United States in developing its sphere of influence in the Western Hemisphere in the nineteenth century relied on the then superpower Britain (then in relative decline), to enforce the Monroe Doctrine until the United States was sufficiently strong to do so itself. ${ }^{81}$

Is the revival in Indian strategic thinking about a sphere of influence merely a defensive reaction to perceived intrusions of China into India's strategic space or is it derived from India's ambitions as a great power? Neorealists argue that it is natural for especially powerful states to seek regional hegemony. They may explain the development of a sphere of interest in terms of small states electing to bandwagon with a larger power instead of balancing against it. ${ }^{82}$ From a geopolitical perspective, spheres of influence are seen as a normal part of ordering the international system. According to Cohen: “... spheres of influence are essential to the preservation of national and regional expression....the alternative is either a monolithic world system or utter chaos." 83 The expression of a sphere of influence over the Indian Ocean region up to Singapore and beyond might be seen as India reasserting an historical or geographical role that was interrupted by India's post-

\footnotetext{
${ }^{81}$ Dean G. Acheson, A Democrat Looks at his Party (New York: Harper, 1955), 64.

82 Walt, The Origins of Alliances, 23-4.

${ }^{83}$ Saul Cohen, Geography and politics in a world divided (2d ed.) (New York: Oxford University Press, 1973), viii.
} 
independence self-limitations, limitations which India is now consciously seeking to overcome.

However, China also provides good defensive reasons for the development of a sphere of influence. Many Indian strategists see China's actions in Southern Asia, including its consolidation of Tibet, its alliance with Pakistan and its relationships with Burma, Bangladesh and Nepal as part of a cohesive and successful policy of "encirclement" or "containment" of India. The expansion of China's relationships and interests across the Indian Ocean - its so-called String of Pearls strategy - is viewed by many among the Indian security community as primarily motivated by a strategy of maritime encirclement of India. ${ }^{84}$ The development of a "defensive" sphere of influence is thus justified by China's actions in South Asia and the Indian Ocean. As the former Indian Chief of Naval Staff, Admiral Arun Prakash, commented: "The appropriate counter to China's encirclement of India is to build our own relations, particularly in our neighbourhood, on the basis of our national interests and magnanimity towards smaller neighbours...." 85

Some "hawks" claim China's putative encirclement strategy justifies a more offensive approach by India, advocating a policy of "counter-encirclement" of China, including the development of security relationships along China's periphery in Southeast and Northeast Asia and North and Central Asia. ${ }^{86}$ The development by India of security-related facilities in

\footnotetext{
${ }^{84}$ For examples of Indian claims about China's String of Pearls strategy, see Ramtanu Maitra, "India bids to rule the waves," Asia Times, 19 October 2005; Sudha Ramachandran, "China moves into India's back yard," Asia Times, 13 March 2007; and Brahma Chellaney, "Assessing India's Reactions to China's “Peaceful Development" Doctrine," NBR Analysis, 18/5 (April 2008).

${ }^{85}$ Admiral Arun Prakash, "China and the Indian Ocean Region" Indian Defence Review, 2/4 (October - December 2006), 7-12 at 11.

${ }^{86}$ See, for example, Colonel Gurmeet Kanwal, "Countering China's Strategic Encirclement of India," Indian Defence Review, 15/3 (July-September 2000), 17; Bharat Karnad, Nuclear Weapons and Indian Security: The Realist Foundations of Strategy (Delhi : Macmillan India, 2005); Mohan Malik, "Sino-Indian Relations in the 21st Century: The Continuing Rivalry," in Brahma Chellaney (ed.), Securing India's Future in the New Millenium (New Delhi: Centre for Policy Research, 1999); and
} 
Tajikistan and Mongolia are taken as evidence of India's counter-encirclement strategy in Central and North Asia and such a strategy might be seen as driving India's relationships with Vietnam, Taiwan, South Korea and Japan on China's eastern periphery. A counterencirclement strategy is also used to advocate the development of a direct India security presence on China's periphery, including Indian control of the Malacca Strait and ultimately an Indian naval presence in the South China Sea and even possibly in the Sea of Japan. ${ }^{87}$

Many Indian strategists would strongly reject any proposition that India is involved in any counter-encirclement strategy against China. Some are beginning to advocate co-operative ways of addressing the apparent Sino-Indian security dilemma in the Indian Ocean. India's National Security Advisor, Shiv Shankar Menon, recently unofficially proposed the discussion of collective maritime security arrangements among all the major powers concerned in the Indian Ocean and the Western Pacific (i.e. including the United States and China) in order to minimise the risk of interstate conflict and threats from piracy and terrorism. ${ }^{88}$ Clearly, such an arrangement might be a useful way of mitigating the maritime security dilemma in the Indian Ocean. Arguably, it might also institutionalise a leading maritime security role for India in the Indian Ocean and a security role for India in Southeast Asia and the Western Pacific. The development of a working concert of major powers with a limited focus on maritime security would also have obvious implications for the broader Asian security order consistent with India's overall objective of developing a multipolar order.

\section{Conclusion}

India has not articulated any "grand strategy" about East Asia and seems unlikely to do so any time soon. As a result, Indian strategic thinking about East Asia is best understood as a

Iskander Rehman, "Keeping the Dragon at Bay: India's Counter-Containment of China in Asia," Asian Security, 5/2 (May 2009), 114-143.

87 Karnad, Nuclear Weapons and Indian Security, p.541 and Mohan Malik, "China's Strategy of Containing India" Public Interest News Report, 6 February 2009. <www.pinr.com>.

${ }^{88}$ Shiv Shankar Menon, "Maritime Imperatives of Indian Foreign Policy," speech to the National Maritime Foundation, New Delhi, 11 September, 2009. 
mosaic of perspectives and pragmatic goals which often cross ideological boundaries. It is, however, possible to identify two key factors that are driving Indian strategic thinking about East Asia: rivalry with China (which is essentially a reactive dynamic) and India's ambitions to achieve great power status (essentially an active dynamic).

Fears of possible Chinese hegemony in East Asia and of Chinese "intrusions" into India's strategic space in South Asia and the Indian Ocean region have led to greater prominence in realist thinking about balancing China. From India's perspective this is a significant factor in its relationship with the United States and Japan and smaller states such as Singapore and Vietnam (although such motivations may not necessarily be reciprocated in Southeast Asia). However, India's ability to enter into any balancing coalition with the United States and its allies is limited by its objectives of maintaining strategic autonomy and avoiding overt rivalry with China.

Beliefs about India's destiny as a great power underlie a separate stream of strategic thinking, one more rooted in geopolitical perspectives. India's strategic outlook is increasingly oriented towards a maritime perspective, driving its aspirations to become the predominant naval power in the Indian Ocean. Related to these ambitions are ideas about the development of an Indian sphere of influence which, among other things, would encompass the littoral states in the northeast Indian Ocean. As a result, India is increasingly projecting naval power into Southeast Asia, although it has been careful to do so in a cooperative manner. The challenge for India in coming years will be how to expand its influence in East Asia in a way that is seen as constructive for regional security.

\section{Note on Contributor}

Dr David Brewster is a Visiting Fellow at the Strategic and Defence Studies Centre, Australian National University. He has written widely on Indian strategic affairs and is the author of India as an Asia Pacific Power and a forthcoming book India as an Indian Ocean Power.

\section{Bibliography}


“PM's Address at the Combined Commander's Conference," 24 October 2004.

<http://pmindia.nic.in/speech/content.asp?id=432>.

Acheson, Dean G., A Democrat Looks at his Party (New York: Harper, 1955).

Ayoob, Mohammed, India and Southeast Asia : Indian perceptions and policies (New York: Routledge, 1990).

Bajpai, Kanti, "India: Modified Structuralism," in Muthiah Alagappa (ed.), Asian Security Practice: Material and Ideational Influences (Stanford: Stanford University Press, 1998).

Bajpai, Kanti, "Indian Strategic Culture" in Michael R. Chambers, South Asia in 2020: Future Strategic Balances and Alliances (Carlisle, PA: Strategic Studies Institute, 2002).

Banyan, "The notion that geography is power is making an unwelcome comeback in Asia" The Economist, 11 June 2009.

Baruah, Amit ,"Not seeking exclusive sphere of influence," The Hindu, 11 February 2007.

Batabyal, Anindya, "Balancing China in Asia: A Realist Assessment of India's Look East Strategy," China Report (New Delhi), 42/2 (2006), 79-197.

Brewster, David, "The strategic relationship between India and Vietnam: The search for a diamond on the South China Sea?" Asian Security, 5/1 (January 2009), 24 - 44.

Brewster, David "An Indian sphere of influence in the Indian Ocean?" Security Challenges, 6/3 (Spring 2010), 1-20.

Brewster, David "The India - Japan Security Declaration: an enduring security partnership?" Asian Security, 6/2 (2010), 1-27. 
Brewster, David, "The evolving security relationship between India and Indonesia" Asian Survey, 51/2 (March/April 2011), 221-244.

Brewster, David, India as an Asia Pacific Power (London: Routledge, 2011).

Cha, Victor D., "The Ideational Dimension of America's Alliances in Asia," in Amitav Acharya and Evelyn Goh (eds.), Reassessing Security Cooperation in the Asia Pacific: Competition, Congruence and Transformation (Cambridge: The MIT Press, 2007), 41-70.

Chaudhuri, Rudra, "Why Culture Matters: Revisiting the Sino-Indian Border War of 1962," Journal of Strategic Studies, 32/6 (December 2009), 841-869.

Chellaney, Brahma and Horimoto Takenori, "“Indo kara mita Nihon, Ajia" [Japan-India Links Critical for Asia-Pacific Security] Gaiko Forum, 7/2 (Fall 2007).

Chellaney, Brahma, "Assessing India's Reactions to China's "Peaceful Development" Doctrine," NBR Analysis, 18/5 (April 2008).

Chellaney, Brahma, "Towards Asian power equilibrium," The Hindu, 1 November 2008.

Cohen, Saul, Geography and politics in a world divided (2d ed.) (New York: Oxford University Press, 1973).

Cohen, Saul Bernard, Geopolitics of the World System (Lanham: Rowman \& Littlefield, 2003).

Devare, Sudhir, India and Southeast Asia: Towards Security Convergence, (Singapore: Institute of Southeast Asian Studies, 2006).

Frankel, Francine R. and Harry Harding (eds.), The India-China Relationship: Rivalry and Engagement (New Delhi: Oxford University Press, 2004). 
Ganguly, Sumit, Brian Shoup, and Andrew Scobell (eds), US-Indian strategic cooperation into the 21st century: more than words (London: Routledge, 2006).

Garver, John W., "Chinese-Indian Rivalry in Indochina," Asian Survey, 27/11 (Nov. 1987), 1205-1219.

Gopalan, Sita, India and Non-Alignment (New Delhi: Spick \& Span, 1984).

Gray, Colin S., The geopolitics of the nuclear era: heartland, rimlands, and the technological revolution (New York: Crane, Russak, 1977).

Gupta, Amit, "US-India-China: Assessing Tripolarity," China Report (New Delhi), 42/1, (2006), 69-83.

Holmes, James R., Andrew C. Winner and Toshi Yoshihara, Indian Naval Strategy in the 21st Century (London, Routledge, 2009).

Holmes, James R.and Toshi Yoshihara, “India's 'Monroe Doctrine’ and Asia’s Maritime Future," Strategic Analysis, 32/6 (November 2008), 997- 1011.

Ikenberry, G.John, Liberal order and imperial ambition: essays on American power and world politics (Malden, MA : Polity, 2006).

Jain, Purnendra, “From Condemnation to Strategic Partnership: Japan's Changing View of India (1998-2007)", Institute of South Asian Studies Working Paper No.41, 10 March 2008.

Jaipal, Rikhi, Non-Alignment: Origins, Growth and Potential for World Peace (New Delhi: Allied Publishers, 1983). 
Joint Statement of Prime Minister Singh and Prime Minister Abe, 16 December 2006. <http://www.kantei.go.jp/foreign/abespeech/2006/12/15joint.pdf>.

Kanwal, Colonel Gurmeet, “Countering China's Strategic Encirclement of India," Indian Defence Review, 15/3 (July-September 2000), 17.

Karnad, Bharat, "India's Future Plans and Defence Requirements" in N.Sisodia and C.Udaya Bhaskar (eds), Emerging India: Security and Foreign Policy Perspectives (New Delhi: Institute for Defence Studies and Analysis, 2005), 61-76.

Karnad, Bharat, Nuclear Weapons and Indian Security: The Realist Foundations of Strategy (Delhi : Macmillan India, 2005).

Latif, Asad-UI Iqbal, Between Rising Powers: China, Singapore and India, (Singapore: ISEAS Publishing, 2006).

Mahan, A.T., The Influence of Sea Power on History, 1660-1783 (Boston: Little Brown \& Co).

Maitra, Ramtanu, "India bids to rule the waves," Asia Times, 19 October 2005.

Malik, Mohan, "Sino-Indian Relations in the 21st Century: The Continuing Rivalry," in Brahma Chellaney (ed.), Securing India's Future in the New Millenium (New Delhi: Centre for Policy Research, 1999).

Malik, Mohan, "China's Strategy of Containing India" Public Interest News Report, 6 February 2009. <www.pinr.com>.

Menon, Shiv Shankar, "Maritime Imperatives of Indian Foreign Policy," speech to the National Maritime Foundation, New Delhi, 11 September, 2009.

Ministry of Defence, Annual Report 2000-2001. 
Mohan, C.Raja, "The Asian balance of power" Seminar, 487 (2000).

Mohan, C.Raja, "India and the Balance of Power," Foreign Affairs, 85/4 (July/August 2006), 17.

Mohan, C.Raja, "India, China and Asian Security," The Hindu, January 27, 2003.

Mohan, C.Raja, Crossing the Rubicon: The Shaping of India's New Foreign Policy (New York: Palgrave Macmillan, 2003).

Mohan, C.Raja, “Balancing Interests and Values: India's Struggle with Democracy Promotion," The Washington Quarterly, 30/3 (Summer 2007), 99-115.

Mohan, C.Raja, “India's Changing Strategic Profile in East and Southeast Asia," paper presented at the Regional Outlook Forum, Singapore, 8 January 2008.

Mohan, C.Raja, "Is India an East Asian Power? Explaining New Delhi's Security Politics in the Western Pacific," ISAS Working Paper No.81, 11 August 2009.

Mohan, C.Raja, "Maritime Power: India and China turn to Mahan," ISAS Working Paper No. 71,7 July 2009, 9.

Mohan, C.Raja, "The Evolution of Sino-Indian Relations: Implications for the United States," in Alyssa Ayres and C.Raja Mohan, Power Realignments in Asia: China, India and the United States, (New Delhi: Sage Publications, 2009), 270-290.

Mukherjee, Pranab, Address to the 7th Asian Security Conference, 29 January 2005.

Mukherjee, Pranab, Address to the 5th IISS Asian Security Summit, 3 June 2006. 
Mukherjee, Pranab, Speech for the Admiral A. K. Chatterjee Memorial Lecture, Kolkata, 30 June 2007.

Panikkar, K.M. ,The Future of Southeast Asia: An Indian View, (New York: The Macmillan Company, 1943).

Panikkar, K.M., India and the Indian Ocean: An Essay on the Influence of Sea Power in Indian History (Bombay: George Allen \& Unwin, 1971).

Prakash, Admiral Arun, "China and the Indian Ocean Region" Indian Defence Review, 21/4 (October - December 2006), 7-12.

Rajagopalan, Rajesh and Varun Sahni, "India and the Great Powers: Strategic Imperatives, Normative Necessities," South Asian Survey, 15/5 (2008), 5-32.

Rajan, Mannaraswamighala Sreeranga, Studies on nonalignment and the nonaligned movement: theory and practice (New Delhi: ABC Publishing House, 1986).

Rajghatta, Chidanand, “Singhing Bush's Praise," Times of India, 13 April 2001.

Ramachandran, Sudha, "China moves into India's back yard," Asia Times, 13 March 2007.

Raman, B., "India \& Japan: Democracy as a Strategic Weapon” South Asia Analysis Group, Paper No. 206, 17 December 2006.

Rehman, Iskander, "Keeping the Dragon at Bay: India's Counter-Containment of China in Asia," Asian Security, 5/2 (May 2009), 114-143.

Roy-Chaudhury, Rahul ,Sea Power and India's Security (London: Brassey's, 1995). 
Sagar, Rahul, "State of mind: what kind of power will India become," International Affairs, 85/4 (2009), 801-816.

Sahni, Varun, "India and the Asian Security Architecture," Current History, Vol.105 (690) (April 2006), 163-7.

Sahni, Varun, "India's Security Challenges out to 2000" paper presented at the AustraliaIndia Security Roundtable, Canberra, 11-12 April 2005.

Saran, Shyam, "India and its Neighbours", address in New Delhi, 14 February 2005. $<w w w . m e a i n d i a . n i c . i n>$.

Scott, David, "India's "Grand Strategy for the Indian Ocean: Mahanian Visions," Asia-Pacific Review, 13/2 (2006), 97-129.

Scott, David, "India's Drive for a Blue Water Navy," Journal of Military and Strategic Studies, 10/2 (Winter 2007-08), 1-42.

Sikri, Rajiv, Challenge and Strategy: Rethinking India's Foreign Policy (New Delhi: Sage, 2009).

Singh, Manmohan, "PM's Speech at India Today Conclave" 25 February 2005, New Delhi. $<w w w . p m i n d i a . n i c$. in/speech/content.asp?id=510 $>$.

Singh, Manmohan, "Address at the 16th Asian Corporate Conference," Mumbai, 18 March 2006.

Sisodia, N.S.and Sreeradha Datta, Changing Security Dynamics in Southeast Asia (New Delhi: Magnum Books, 2008). 
Sridharan, Kripa, The ASEAN Region in India's Foreign Policy (Aldershot: Dartmouth Publishing, 1996).

Subrahmanyam, K., Indian security perspectives (New Delhi: ABC, 1982).

Subrahmanyam, K., "Slumber over National Security" Economic Times (New Delhi), 31 October 2000.

Tanham, George, "Indian Strategic Thought: An Interpretive Essay," in George K. Tanham, Kanti P. Bajpai and Amitabh Mattoo (eds), Securing India: Strategic Thought and Practice in an Emerging Power, (New Delhi: Manhora, 1996), 73.

Tellis, Ashley J., "The Changing Political-Military Environment: South Asia” in Zalmay Khalilzad et al, The United States and Asia: Towards a New US Strategy and Force Posture (Santa Monica: Rand Corporation, 2001), 214.

Tellis, Ashley, India as a New Global Power: An Action Agenda for the United States (Washington D.C.: Carnegie Endowment for World Peace, 2005).

Tellis, Ashley J., "India in Asian Geopolitics" in Prakash Nanda (ed.), Rising India: Friends and Foes, (New Delhi: Lancer, 2007), 129.

van der Wusten H. and G. Dijkink, "German, British and French Geopolitics: The Enduring Differences," Geopolitics, Vol. 7, Iss. 3 (Winter 2002), 19 - 38.

Varadarajan, Siddharth, "Bush, India and two degrees of separation," The Hindu, 3 March 2006

Walt, Stephen M., The Origins of Alliances (Ithaca: Cornell University Press, 1987). 